\title{
3. The pervasive power of man-made news
}

\begin{abstract}
Since the first woman was appointed as editor of a major newspaper in New Zealand in the mid 1980s, what has been the progress of women to top editorships? And what is the status of women at governance, management and staff journalist levels? These questions examine gender equality issues and are important given the power and ubiquity of the news media in modern society. The article analyses participation of women in the news media against the so-called 'feminisation' of pre-entry journalism training. The findings show that little progress has been made at editorship level, while there is more progress for senior women just below editorship level. Further, there is a difference in the status of women in governance of public service versus privately-owned broadcasting. The article is critical of the data available to monitor participation by gender and ethnicity in New Zealand journalism over time. Strategies to help break down the pervasive power of 'man-made news' are proposed. These include female shareholder activism at the governance level of media companies, and a greater commitment by the New Zealand Journalism Training Organisation to regular monitoring of women's newsroom participation. Without it the status of women in New Zealand journalism remains invisible.
\end{abstract}

JUDY McGREGOR

Equal Employment Opportunities Commissioner, NZ

\section{Introduction}

N THE mid 1980s I became the first female to edit a major newspaper in Australasia, the big-selling tabloid Sunday News in New Zealand. The newspaper was then owned by Independent Newspapers Ltd, a company with a sizeable News Ltd shareholding. Global media baron Rupert Murdoch 


\section{CONTEMPORARY GENDER ISSUES}

had established no previous reputation for advancing the cause of women in journalism.

The Sunday News was an unlikely publication for a self-confessed feminist to edit. The weekend newspaper contained all the usual tabloid suspects, including a Page Three Girl who came courtesy of News Ltd clipping rights from the Sun newspaper in London. Prior to accepting my editorship I had decided to remove the Page Three Girl because the topless models degraded women. They also insulted readers' intelligence because while it was common knowledge that the photographs were sourced from overseas, the newspaper had kept up a façade of situating the bikini-clad models on local Auckland beaches in captions such as 'Sultry Samantha suns herself and laps up attention on Takapuna Beach'.

When my intentions to remove Page Three became clear I was warned by the publisher, News Media (Auckland) Ltd, that the company could not afford a fall in circulation. The Sunday News had a strong male readership demographic largely attributed in the urban mythology to the circulationboosting powers of topless girls. A buying campaign to prop up circulation was informally orchestrated among women and media groups some of whom had never previously bought the paper. The circulation of Sunday News climbed in subsequent months to its highest-ever figure, more than 270,000 copies a weekend, largely because women bought the paper in roughly the same proportion as men. Men also quietly acknowledged that while they could do without Page Three they could not do without knowledge of Saturday night's sports results.

After editing Sunday News and a stint in publishing management I went on to edit an afternoon newspaper, the Auckland Star, again the first woman to edit a metropolitan daily in New Zealand. I finally left the Murdoch empire after a row over the Star's editorial direction and I was that newspaper's third to last editor before it succumbed to the world-wide trend of afternoon newspaper closures.

Since those days I have maintained an interest in the participation and status of women in the media and their representation in the news. So what is the position of women in the media in New Zealand 20 years on? The question has a special significance because the New Zealand and international media have focused on the perceived predominance of women across some of the country's key leadership positions during recent years. The perceived 
predominance includes successive female Prime Ministers, a female Chief Justice, a female Speaker of the House and until recently two females have led the two major telecommunication companies in New Zealand as chief executive officers. But as one of the New Zealand women in a key leadership position, the Governor-General, Dame Silvia Cartwright, notes such attention, however positive, carries the risk of a double-edged sword. 'It is all too convenient to assume that this profile accurately reflects the status of all professional women' (Cartwright, 2004).

This article examines the status of women in the New Zealand media by examining their representation at governance level, and in newspaper editorships and broadcasting executive positions. The paper argues that unless women have attained positions at the decision-making level or serve on governing boards they cannot influence media policy. It also discusses why women's status is so low, given the so-called 'feminisation' of the media in the past 30 years. The gender analysis undertaken leads to consideration of several appropriate entry points to improve equality of women's status. These include several strategies for improving women's representation at the top of media structures to challenge men's pervasive power in making the news.

\section{Governance}

In assessing the progress women have made in participating and assuming responsibility in the media it is important to look at governance structures of major New Zealand media companies. It is at the governance level that owners and shareholders provide strategic direction to media companies. This impacts both directly and indirectly on editorial control of publicly and privately owned media companies. In particular, governance is linked to what Murdock (1977) described as allocative control as opposed to operational control. Allocative control operates on the higher general level concerned with the structure and development of the media enterprise as a whole. The scale and scope of the media's activities and the overall allocation and use of resources, such as the hiring and the firing of editors, operates at this level.

Directors of boards wield power and influence and there are compelling social justice and business cases for women's representation on the boards of directors. The social justice case is based on diversity, anti-discrimination and equal opportunities for women in all spheres of life, particularly the media which is an essential service and helps powerfully construct our view of 


\section{CONTEMPORARY GENDER ISSUES}

the world and ourselves. The business case for women in the boardroom suggests that women bring to boards important insights into products and markets and therefore increase competitive advantage (Morrison, 1992).

Looking at the companies that own the media in New Zealand, two issues are immediately apparent. First, the New Zealand media is a mixture of corporate (mainly international media conglomerates) and public service ownership and these different ownership patterns significantly influence board composition. As Norris (2002) states media ownership matters because it confers power. Second, there is a marked difference in the gender representation of women on the boards of publicly-owned broadcasting in New Zealand by comparison with privately-owned broadcasting (see Table 1). This difference, with a greater balance of women and men on publicly-owned broadcasters in radio and television, is partly the result of successive New Zealand Governments' commitment to improving gender representation in Crown companies. By contrast, international media conglomerates reflect global corporate patterns of gendered governance with few women at the top.

The progress of New Zealand women on public boards, including broadcasting organisations, follows the country's international obligations under the Convention on the Elimination of all Forms of Discrimination Against Women (CEDAW), which New Zealand ratified in 1985. The CEDAW report in 2003 noted the under-representation of women in public life, particularly with respect to chief executives in the public sector and on crown company boards. The Ministry of Women's Affairs in its latest action plan is targeting a 50/50 ratio by 2010 in relation to public appointments on Crown companies and Government-appointed bodies, largely in response to CEDAW and whole-of-government policy commitments. The following data has been purchased from the New Zealand Exchange (NZX) and after being compiled from company websites as at 26 April 2006 or from 2005 company annual reports to illustrate the gender composition of broadcasting companies at governance level.

\section{Media companies}

Turning to the print media - traditionally regarded as 'the press' - gone are the days of independent ownership by New Zealand families such as the Hortons, the Blundells and the Harknesses. Only one family, the Smiths in Dunedin, independently owns a significant newspaper company in New Zealand, Allied Press Ltd, while there remain smaller family concerns and sig24 PACIFIC JOURNALISM REVIEW 12 (1) 2006 
CONTEMPORARY GENDER ISSUES Table 1: Broadcasting companies - Gender composition of board

\begin{tabular}{lcll} 
Company & Male & Female & \\
Radio New Zealand (public ownership) & 5 & 3 & \\
Television New Zealand (public ownership) & 6 & 2 & \\
Maori Television Service (public ownership) & 4 & 3 & \\
Total & 15 & $\mathbf{8}$ & $\mathbf{3 4 . 7 8 \%}$ \\
Canwest Mediaworks NZ Ltd (private ownership) & 6 & 1 & \\
SKY TV (private ownership) & 7 & 0 & \\
Total & 13 & $\mathbf{1}$ & $\mathbf{7 . 1 4 \%}$ \\
\hline
\end{tabular}

nificant family shareholdings in international conglomerates. The majority of New Zealand's newspapers and magazines is owned by two international media companies, who own roughly half each. APN News \& Media publishes the New Zealand Herald, as well as regional and community newspapers, and magazines, and has 116 radio stations in New Zealand. John Fairfax Holdings Ltd is Australasia's largest newspaper publishing group and its New Zealand mastheads include the Dominion Post, The Press, and two Sunday newspapers as well as community newspapers and magazines. Norris (2002, p. 45) states that the extent of foreign ownership of the media matters because 'foreign private owners have no particular concern for our national identity and culture'.

\begin{tabular}{|c|c|c|c|}
\hline Company & Male & Female & \\
\hline APN News and Media (media transnational) & 12 & 1 & \\
\hline John Fairfax Holdings Ltd media (transnational) & 6 & 1 & \\
\hline Allied Press Ltd (independent NZ owned) & 3 & 0 & \\
\hline Total & 21 & 2 & $8.69 \%$ \\
\hline
\end{tabular}

The results show a depressing female tokenism in corporate media governance in New Zealand (Table 2). The publicly-owned broadcasting media show, by contrast, that a reservoir of skilled, experienced and qualified women is available in New Zealand to help guide the strategic direction of media companies. Overall, this brief audit of the status of women on the boards of major New Zealand media companies shows that the media, despite being essential services, are no more enlightened than the rest of the private sector where only 5.04 per cent of directors of the top 100 publicly listed companies on the NZX are women (Olsson \& McGregor, 2004). 


\section{CONTEMPORARY GENDER ISSUES}

\section{Newspaper editorships}

Monitoring of major newspapers reveals that New Zealand is making little progress in the appointment of women to editorships of prominent newspapers. Media directories were used to compile the information as at November 2005. The data was subsequently checked by the NZ Journalism Training Organisation (JTO) executive director. Table 3 shows that of the five metropolitan daily newspapers in the North and South Islands, none is currently edited by women. Of the 18 provincial daily newspapers, four are edited by women. Of the three Sunday newspapers that are published weekly, one, the Sunday Star-Times, with a particular tradition of female editors, is currently edited by a woman, Cate Honore Brett.

An analysis of the executive teams of the five metropolitan dailies shows that greater numbers of women, 18 of the 56 positions ( 32 percent), are sitting just beneath the editorship level in positions such as chief reporter, chief of staff or assistant editor. Major editorships, though, continue to remain elusive for women.

Several well-known women have been, or are, chief executive officers of major media companies. In recent history, Radio New Zealand (RNZ) has had two female chief executives. These were Beverley Wakem, who engaged the rest of the media in a public fight over gender issues when she banned a list of 140 sexist words from news and advertising on state radio, and Sharon Crosbie, a former broadcaster and more recent RNZ chief executive. Joan Withers, a former chief executive of the Radio Network and a professional director of several large companies, was appointed chief executive officer of Fairfax New Zealand Ltd in 2005, a significant appointment given the power and reach of Fairfax in the Australasian market. She resigned from the board of John Fairfax Holdings Ltd to take up the senior management position.

\section{Tracking women's progress}

Other major areas of journalism also show that women have made significant progress. It is nearly 40 years since the first woman, Fran Collett, joined the New Zealand Parliamentary Press Gallery, where privilege and power underpin political reporting. Riddell (2002) reported that more than half the current fulltime members of the Press Gallery (21 of 41) were women.

Traditionally, too, there has been a greater proportion of women editing community newspapers and magazines in New Zealand. Of the 151 commu- 
CONTEMPORARY GENDER ISSUES

\section{Table 3: Newspaper editorships - Gender composition of editors}

Metropolitan dailies
New Zealand Herald
Waikato Times
Dominion Post
The Press (Christchurch)
Otago Daily Times

Male Female

-
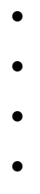

$\bullet$

$\bullet$

Provincial dailies Northern Advocate

Bay of Plenty Times

Taranaki Daily News

The Daily Post

Gisborne Herald

Hawke's Bay Today

Manawatu Standard

Wairarapa Times Age

Wanganui Chronicle

Horowhenua-Kapiti Chronicle

Ashburton Guardian

The Greymouth Evening Star

The Marlborough Express

The Nelson Mail

Oamaru Mail

The Southland Times

The Timaru Herald

West Coast Times

\section{Sunday papers}

Sunday Star-Times

Sunday News

Herald on Sunday

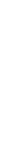




\section{CONTEMPORARY GENDER ISSUES}

nity newspapers listed in Mediapeople (2005), 62 were women compared with 89 men. Women, too, feature in the huge range of magazines on sale and particularly dominate the hugely lucrative and competitive women's magazine market.

Unfortunately, baseline data to assess whether women have made progress in journalism overall is inadequate. In an early study of New Zealand journalists by Campbell and Cleveland in 1972, female journalists comprised 18.4 percent of the sample of 418 journalists. In 1988, the JTO conducted the first National Survey of New Zealand Journalists (Lealand, 1988). By then the gender gap had closed considerably, with women making up 46 percent of all journalists. Lealand indicated in that survey that gender inequalities were most pronounced in newspaper journalism. Of the category described as 'editor/senior editor', a total of 126 respondents was split between the sexes, at 66 percent male and 34 percent female. The survey was repeated in 1994, when 45.3 percent of respondents were listed as women, and of the 'editor/ senior editor' category 140 males and 84 females responded. The numbers included community newspapers, broadcasting editors and probably senior subeditors, which explains the difference between these more positive figures and those reported in this paper. In the latest survey conducted in 2003, far fewer numbers of journalists responded — only 297 compared with more than 1200 in previous surveys, a small proportion of the census of journalists in New Zealand. As a consequence of the low response rate, the report does not claim a similar national status (Lealand, 2004). The gender data in the latest survey shows a rise in the proportion of women to men, with 53 percent female respondents compared to 47 percent men.

Increasing numbers of young women have entered journalism in the past 30 years. The perceived imbalance of young women to young men undergoing pre-entry journalism training so worried some senior industry figures that at one editors' conference run by Independent Newspapers Ltd (INL) as far back as the 1980s there was discussion about how to 'correct' the trend and attract more young men (McGregor, 1992). Christchurch broadcasting school academic Yvonne Densem (2004) has researched the gender imbalance in tertiary journalism courses in New Zealand. (See following article, pp. 37-53). Over her years on the selection panel for a broadcast journalism course, she observed that few men applied for the course, fewer received an interview and still fewer won a place on the course. 
However, the paucity of quality data makes it difficult to accurately generalise about the extent to which journalism has become feminised in New Zealand, and to accurately monitor and report on the status and progress of women in the profession. What is known is that for many years more women than men have entered pre-entry journalism training. The fact that women do not make it into editorships or other senior editorial positions in anything like the proportion they should, given their entry ratios and the proportion of women in positions just below the rank of editor, is also well established.

The absence of benchmark information to track the demographics of journalism should be of concern to the JTO and the news media generally. Succession planning for senior editorial positions would be informed by better knowledge and more diverse newsrooms would better fit the changing demographic profile of society. Not only are accurate figures needed by gender, other information would also be useful. This includes qualitative data to test women's and men's retention levels, reasons for leaving or re-entering the profession and an examination of career aspirations and career progression.

\section{What are the reasons for few women at the top?}

A complex array of reasons accounts for women's snail-like progress towards the editorships of leading newspapers and positions of authority in broadcasting. The old theory of incrementalism - that women only need to wait their turn until the numbers in the profession reach a critical mass in senior positions to break through the 'glass ceiling' is, however, a myth.

Despite the complexity of the issue, there are some very obvious reasons why women are not prominent in positions of editorial authority in the news media. The uncomfortable reality for those who work in the news media is that in general, media companies are traditionally renowned for their ruthless approach to people, and in particular to journalists. The news media are deadline-driven, have a resilient sense of self-identity, are aggressive and competitive and are notoriously immune to leading-edge human resource theory and practice. The news media still rewards for 'presenteeism' and for 'toughness' against the perceived wisdom of contemporary employment practice that places a premium on quality, communication and effective relationships. The gender implications suggest many women opt not to seek senior editorial roles given this environment.

The news media are ratings or circulation driven and the intense compe- 


\section{CONTEMPORARY GENDER ISSUES}

tition influences the nature of employee relations, while it does not excuse them. A recent and very public example of highly charged employer-employee friction concerns the dumping of One News executive producer Melanie Jones (Venter, 2005). After TV One won the major broadcasting trophies at the 2005 media awards, Melanie Jones received a glowing letter from TVNZ's head of news and current affairs, Bill Ralston, paying tribute to the standards she set. Four months later she was sacked by him when ratings fell in a meeting that lasted just five minutes which she described as 'brutal' and 'unexpected'. Ralston's subsequent address to staff described TVNZ's ratings in metropolitan areas and among women as 'unsustainable' (Venter, 2005).

The fast-paced and fierce competition makes it difficult for progressive news managers to introduce ideas such as the value of diversity, work-life balance or flexible work and family-friendly practices such as job-sharing. The timing of news is unpredictable, and the unremitting nature of news production cycles does not easily accommodate family demands. Deadline pressures which are increasingly compressed add to job stress. Women, traditionally the primary care-givers, have found it even more difficult than in other careers to reconcile work and family life with work in daily journalism. Structural and systemic change at an institution level would be needed to alter the dynamics of news media employment values and practices. This may be unlikely in the current global media market.

The culture of many newsrooms is unfriendly to women, families, Maori and ethnic minorities and many men making newsroom journalism unattractive. Many trained journalists, both women and men, decide after graduation from journalism schools that a news apprenticeship to develop transferable skills is all they want. The evidence for this is the large number of New Zealand-trained journalists who migrate after two or three years to public relations and private and public sector communications. These areas traditionally pay more, provide greater support mentorship and are often more respectful of employees.

\section{Why does it matter if there are no women at the top?}

In an earlier article on women in the media in New Zealand, former journalist, broadcaster and educator Allison Webber (1992, p.186) wrote:

The main thing women want from the media is to be in it. We don't just want to be firsts, bests and onlys, sex symbols, wives, mothers or vic-

30 PACIFIC JOURNALISM REVIEW 12 (1) 2006 
tims. We want to be recognised in both our complexity and diversity. We also want it acknowledged that we have a perspective that's different.

Webber was writing about women as sources of the news and their representation in the news as newsmakers. But equally her comments have relevance for female participation as journalists in print and broadcast media, as editors, as executive news managers, and as women on the boards of directors of news media companies making strategic decisions.

One of the key reasons why it is important to have women at the top in journalism is simply to have a female perspective in the news. Among academic writers the jury is still out over the degree to which women in journalism can alter the male-ness of news. Fountaine (2002, p. 256) notes that a number of overseas writers provide evidence that gendered news coverage shows the media is shaped by men, serves male interests and confines women to the private realms of 'home and hearth'. However, she remains optimistic that there is still potential for more women in journalism to transform the news from the inside through women reporters 'taking female sources seriously and aiming to include a female perspective where relevant'.

In my own analysis of the coverage of women in politics, a range of pessimistic and optimistic views are expressed about the degree to which women in journalism make a difference to news content itself (McGregor, 1996). Former politician and current university academic Dr Marilyn Waring, who was a press victim when Truth 'outed' her as a lesbian in 1976, believes that female journalists bring a professionalism to their reporting of other women. The increase in the number of senior female broadcasters reporting politics made 'a difference to the subject matter that is covered, the language in which it is covered and to something that nobody ever sees, which is the relationship of mutual working respect that professional women can have for each other', she said in an interview in a media textbook (McGregor, 1996). My own verdict at that time was gloomier. I wrote (McGregor, 1996, p. 194) that it was ironic that despite the dynamism of the news, the structures, organisation and values of the news industry were trenchantly conservative and emphatically male. 'They have remained surprisingly impervious to demographic imperatives and the changed nature of female participation in public life and this is reflected in content...' A decade later I have yet to change my mind. 


\section{CONTEMPORARY GENDER ISSUES}

\section{Strategies to challenge the status quo}

A fundamental strategy to challenge the status quo relates to building a common base of knowledge and understanding of the benefits of gender equity in journalism. Media industries are more likely to concern themselves with the absence of women in governance or a lack of women in newspaper editorships when these issues are transparent. Once baseline data is available, it can then be debated in terms of both social justice and business case arguments by all stakeholders both inside and outside the media industry. Without transparency of gender imbalances, the debate about why it is a pattern and what it means will not begin.

Journalism is a Cinderella research topic in New Zealand, which has a weak tradition of practitioner critique and academic scrutiny by comparison with overseas countries. The JTO should be urged to revive its national survey so that valid longitudinal data can be collected and analysed and a commitment made to regular data collection. New information could also be sought from a revised survey tool to better reflect demographic trends and retention patterns.

Female shareholders of media companies can use annual general meetings as an opportunity for shareholder activism. This tactic has been used in the past by a prominent former Wellington City councillor and feminist who asked the chairman of directors of INL in 1988 why a company which employed so many women and which had a substantial female shareholding, had only one female director in the boardroom. Women's activism was also partly responsible for prising open the boardroom door of the telecommunications giant, Telecom, to admit female directors (McGregor, 2000). Shareholder activism is increasingly in vogue internationally in relation to social responsibility and environmental concerns and equally could be a useful way to highlight the gendered nature of media company governance.

By and large, making it to the top of media industries involves sacrifice. Many women with families choose not to make the sacrifice. They will continue to choose not to contest top media jobs while media companies pursue rigid employment practices and while newsroom values and cultures remain unsympathetic in terms of hours of work, the value of the work undertaken and the indifference to a woman's perspective in news content. The feminisation of journalism represents a significant opportunity for the news media industry which it has yet to realise. There is, too, a lost investment in journalism education and training, given the numbers of trained graduates 32 PACIFIC JOURNALISM REVIEW 12 (1) 2006 
who after a year or two migrate to the public relations industry that largely enjoys a free ride in terms of developing the foundation skills that are learnt within schools of journalism.

The final strategy appears at first blush to be trivial but is seldom acknowledged. Women in journalism, particularly those in senior positions, generally feel under-valued, under-supported and quite often isolated, particularly if they are the only senior woman in the structure. The attention, support and publicly expressed goodwill of other women makes a huge difference to their sense of professional self-esteem. As women, we owe it to ourselves and to female journalists to praise them for quality journalism when they are responsible - whether it be a sensible editorial, a well-crafted column or a women's perspective in the news. In journalism, the tiniest bit of positive feedback goes a very long way.

\section{Conclusion}

Information gathered on the status of women in the New Zealand news media shows poor representation at the governance level of privately-owned media companies and in newspaper editorships. The analysis shows that increased feminisation at entry-point level has not markedly improved gender equality at the top over the past 20 years. Aspects of newsroom culture and journalistic traditions that impact on women's choices partly explain the absence of women from major newspaper editorships. Possible strategies to improve gender equality among directors and editors of the New Zealand media include regular industry benchmarking to ensure visibility of women's progress, shareholder activism within media companies and public support for female journalists who in their reporting make a difference to how we see the world. Women's progress in the New Zealand media is important because of its increasingly pervasive power and the impact man-made news has on society.

\section{References}

Campbell, R. J. \& Cleveland, L. (1972). Daily newspaper journalists in New Zealand. Wellington: School of Political Science and Public Administration, Victoria University.

Cartwright, S. (2004). Message from the Governor-General. In Olsson, S. and McGregor, J. (Eds). New Zealand census of women's participation in governance and professional life (p. 2). Wellington: Human Rights Commission.

Densem, Y. (2004). Where have all the young men gone? (pp.36-37). Script. Magazine of the National Association of Media Educators. Issue 60 (October, 2004). 


\section{CONTEMPORARY GENDER ISSUES}

Fountaine, S. (2002). Are we there yet? The long ride to gender equity in the news. In McGregor, J. \& Comrie, M. (Eds). What's news? Reclaiming journalism in New Zealand. (pp.244-258). Palmerston North: Dunmore Press.

Lealand, G. (1988). Anational survey of New Zealand journalists. New Zealand Council for Educational Research.

Lealand, G. (2004). A survey of New Zealand journalists, 2003. Report for the New Zealand Journalists Training Organisation. Hamilton: University of Waikato.

McGregor, J. (1992). Man-made news. In Olsson, S. (Ed), The gender factor: Women in New Zealand organisations.(pp.180-190). Palmerston North: Dunmore Press

McGregor, J. (1996). Gender politics and the news: The search for a Beehive bimboBoadicea. In McGregor, J. (Ed). Dangerous democracy? News media politics in New Zealand. (pp.181-196). Palmerston North: Dunmore Press.

McGregor, J. (2000). Training to be on board as a director. In Burke R.J. \& Mattis M.C. (Eds). Women on corporate boards of directors. The Netherlands: Kluwer Academic Publishers.

McGregor, J. and Comrie, M. (Eds). What's news? Reclaiming journalism in New Zealand. (pp.33-55). Palmerston North: Dunmore Press.

Ministry of Women's Affairs (2004). The action plan for New Zealand women. Wellington: Ministry of Women's Affairs.

Morrison, A.M. (1992). The new leaders: Guidelines on leadership diversity in America. San Francisco: Jossey-Bass.

Murdock, G. (1977). Patterns of ownership: questions of control. Milton Keynes: Open University.

Norris, P. (2002). News media ownership in New Zealand. In McGregor, J. and Comrie, M. (Eds). What's news? Reclaiming journalism in New Zealand (pp. 33-55). Palmerston North: Dunmore Press.

Riddell, O. (2005). A gallery of rogues. In McGregor, J. and Comrie, M. (Eds). What's news? Reclaiming journalism in New Zealand (pp.199-209). Palmerston North: Dunmore Press.

Venter, N. (2005, September 24). What's going on at TVNZ? The Dominion Post, pp. E1-2.

Webber, A. (1992). Women in the media: Wrestling with old values. In Comrie. M. and McGregor, J. (Eds). Whose news? (pp 181-188). Palmerston North: Dunmore Press.

Dr Judy McGregor is Equal Employment Opportunities (EEO) Commissioner, Human Rights Commission, New Zealand. She is a trained lawyer and a former head of the Departments of Human Resource Management and Communication and Journalism at Massey University. Her doctorate is in political communication and she has an arts degree and legal qualifications. She spent 20 years in the newspaper industry, including two editorships, Sunday News and the Auckland Star. JudyM@hrc.co.nz

34 PACIFIC JOURNALISM REVIEW 12 (1) 2006 